\title{
Matti Savolainen
}

\section{Thomas Sutpen ja sokeriruokoviljelmiä Länsi-Intiassa: William Faulknerin Yoknapatawpha ja kolonialismi ${ }^{1}$}

Artikkelini lähtökohdat nousevat kahtaalta. Ensinnäkin luentani malli ja innoitus löytyvät Edward Saidilta ja hänen Jane Austen -tulkinnastaan (Said 1993, 95-116; Savolainen 1998, 23-24). Tarkoitan monille tuttua luentaa Austenin 1814 ilmestyneestä romaanista Mansfield Park (Kasvattitytön tarina, 1956), jossa Said nostaa kontrapunktisesti esiin sen toisen ja traditionaalisesti hiljennetyn narratiivin, joka itse asiassa tekee koko Mansfield Parkin laajoine tiluksineen mahdolliseksi - juuri siksi näyttämöksi, jossa naimakauppoja suunnitellaan ja sydämen lankoja kudotaan yhteen englantilaisen maaseudun rauhassa. Tähän idylliin eivät kuulu sokeriruokoviljelmät Karibialla tai englantilaisten käymä orjakauppa, mutta juuri tämän narratiivin Said paljastaa siinä määrin, että Antiguan saari näyttäytyy Mansfield Parkin hiljennettynä toisena.

Hyvin samankaltainen asetelma löytyy William Faulknerin romaanista Absalom, Absalom! (1936). Romaanin keskiössä piilottelee arvoituksellinen Thomas Sutpen, joka ilmestyy Yoknapatawphan piirikuntaan ja rakennuttaa itselleen ja perheelleen suunnattoman plantaasin nimeltään Sutpen’s Hundred. En ole kiinnostunut siitä itsestäänselvyydestä, että Yhdysvaltain sisällissotaan, vuoteen 1861 asti Etelän plantaasien ja pienempienkin tilojen voitot perustuivat orjatyövoiman käyttöön - haluan kohdistaa huomioni siihen, mistä ei romaanissa juurikaan puhuta tai mihin viitataan vain katkelmallisesti siellä täällä. Sutpen’s Hundredilla on hiljennetty toinen, ja se löytyy Karibialta samoin kuin Jane Austenin romaanissa.

Toinen lähtökohta löytyy kolmekymmentä vuotta vanhasta mutta teränsä hyvin säilyttäneestä John Irwinin Faulkner-tutkimuksesta Doubling and Incest/ Repetition and Revenge (1975). Irwin lukee "spekulatiivisesti" rinnakkain ja ristiin kahta Faulknerin romaania The Sound and the Fury (1929) (Ä̈̈ni ja vimma, 1965) ja Absalom, Absalom!, joita yhdistää yhteinen avainhenkilö Quentin Compson². Spekulatiivisuudella ei ole hyvä kaiku humanistisessakaan tutkimuksessa. Englanti-englanti sanakirjani antaa sille seuraavia merkityksiä: (a) spekulatiivisuus on jotain älyllistä ja teoreettista vastakohtana 
empiirisesti todennettavalle; (b) sille on ominaista kyselevä uteliaisuus ja (c) riskin ottaminen (keinottelu). ${ }^{3}$ Ajattelen, että kaikki nämä näkökohdat resonoivat luennassani - myös ajatus tulkinnallisesta keinottelusta.

Luen Faulknerin Absalom, Absalom! romaania rinnakkain ja ristiin kahden kolonialismi / jälkikolonialismi -paradigman kanonisoidun tekstin kanssa: ensimmäinen on Joseph Conradin Heart of Darkness (1902) (Pimeyden sydän, 1967), toinen Jean Rhysin Wide Sargasso Sea (1966), joka puolestaan on Charlotte Brontën Jane Eyren (1847) (Kotiopettajattaren romaanin, 1919, 1985) uudelleenkirjoitus. Luennassani olen kiinnostunut Faulknerin, Conradin ja Rhysin sekä osin myös Brontën teosten välisistä jännitteistä, jotka nostavat esiin teosten koloniaaliset asetelmat ja kysymyksen teosten temporaalisesta organisaatiosta, jossa menneisyys tunkeutuu pakonomaisesti nykyhetkeen ja pyrkii estämään teosten sulkeuman.

Omaksun siis spekulatiivisen otteen valitsemiini teksteihin, mutta esittämäni pohdiskelut ja teoreettinen keinottelu johtaa lopussa esitykseni keskeiseen kysymykseen: mikä on koloniaalinen/jälkikoloniaalinen paradigma tai orientaatio kirjallisuudentutkimuksessa? Mitkä ovat sen rajat? Nämä kysymykset kohdistuvat Clarles Bakerin tutkimukseen William Faulkner's Postcolonial South (2001), jossa Baker tarkastelee Faulkneria kenties yllättävästi jälkikoloniaalisena kirjailijana ja asettaa sisällissodan jälkeisen Etelän jälkikoloniaaliseen kontekstiin. Bakerin tutkimus kertoo siitä uudistuneesta suuntauksesta, jossa Amerikan tutkimus omaksuu myös koloniaalisia/jälkikoloniaalisia näkökulmia (ks. Schueller 2004). Artikkelini asettuu luonnollisesti myös siihen Amerikan tutkimuksen painopisteen siirtymään (ks. Smith 2004), jossa Yhdysvaltain etelävaltiot nähdään suhteessa Karibian alueeseen ja Etelä-Amerikkaan pikemmin kuin omana kulttuurisesti ja yhteiskunnallisesti omintakeisena kokonaisuutena suhteessa Yhdysvaltain pohjoisvaltioihin.

\section{Thomas Sutpen ja Karibia}

Aloitetaan faktoista. Ensimmäiseen maailmansotaan eli vuoteen 1914 asti Eurooppa piti eri tavoin hallussaan n. 85 \% maapallon pinta-alasta (Said 1993, 6). Eurooppalaisina ja eurooppalaisen kulttuurin kasvatteina tällä on mittaamattoman suuri vaikutus siihen miten käsitämme itsemme ja olemisemme maailmassa. Toinen fakta: Useat historioitsijat ovat jokseenkin yksimielisiä siitä, että Englannissa 1700-luvun puolivälissä käynnistynyt teollinen vallankumous ei olisi edennyt yhtä rajusti ilman Englannin siirtomaita ja erityisesti Englannin käymää orjakauppaa. Bristolin, Lontoon ja Liverpoolin satamat ja niiden toimintaa rahoittavat tahot keräsivät suunnattomia voittoja eli siis pääomaa, jolla teollistuminen saatiin käyntiin (Martin 1999/2000, 15-17). Ranskassa erityisesti Nantes ja Bordeaux hyötyivät orjakaupasta (James 1938/1980, 39). Sama pätee olennaisesti moniin muihin Euroopan mahtivaltioihin, joilla oli koloniaalisia pyrki- 
myksiä ja jotka harjoittivat orjakauppaa.

Jane Austeniin suhteutettuna tämä tarkoittaa, että Mansfield Parkin vauraus on otettu Antiguan saarella sokeriruokoa korjaavien orjien selkänahasta - eikä tätä tarvitse lukea rivien välistä, Jane Austen maintsee asian useita kertoja. Sutpens' Hundredin materiaaliset lähtökohdat - se pääoma, jolle tila voitiin rakentaa - tulee sekin Karibialta. Thomas Sutpen ilmestyy jeffersonilaisten ihmeteltäväksi kuin tyhjästä, mukanaan parikymmentä neekeriorjaa ja ranskalainen arkkitehti. Hän ostaa tai huijaa plantaasinsa maa-alan chickasaw-intiaaneilta (AAS, 26; AAE, 34) ja rakennuttaa sille suurimman ökyrakennuksen, jota tultiin ihmettelemään seutukunnan takamailta; kymmenessä vuodessa Sutpen kohoaa piirikunnan suurimmaksi maanomistajaksi ja puuvillan tuottajaksi (AAS, 55; AAE, 72). Kiinnostavaa mielestäni onkin se kiertelevä ja kaarteleva, viipyilevä ja keskeytyvä, spekulaatioiden ja arvailujen leimaama kerrontastrategia, jolla lukija saa tietää itse asiassa hyvin vähän Sutpenin varhaisemmista vaiheista.

Spatiaalisesti hahmotettuna romaanin kerrontaa voi kuvata sisäkkäisinä kehinä, joiden keskellä piileskelee Thomas Sutpen ja kysymykset, kuka hän on ja mitä voimme tietää hänestä. Uloimpana on Quentin Compson eli sama Quentin, joka tekee itsemurhan romaanissa Ä̈̈ni ja vimma. Mutkia oikoen ilmaistuna: tiedonmurusista ja huhuista kokoon parsittu näkemys Thomas Sutpenista tulee lukijalle Quentin Compson versiona, joka pohjaa hänen isänsä Mr. Compsonin kerrontaan. Mr. Compson on puolestaan saanut tietonsa isältään eli Quentinin isoisältä, joka "oikeasti” oli ollut tekemisissä Thomas Sutpenin kanssa ja kuullut tämän puhuvan itsestään. Tähän kerronnalliseen suodattumiseen tuovat vielä omat lisänsä Quentinin vanha täti Rosa Coldfield, joka kertoo Quentinille oman versionsa Thomas Sutpenista, sekä Quentinin kanadalainen opiskelutoveri Shreve McCannon, joka ulkopuolisena kommentoi Quentin kertomusta. Molemmat nuoret miehet opiskelevat Harvardissa Uudessa Englannissa, mihin kerronnan ja muistelemisen nyt-hetki temporaalisesti paikantuu.

Mitä Sutpenin taustasta paljastuu? Sosioekonomiselta taustaltaan hän ja hänen perheensä edusti ns. valkoista roskaväkeä ("white trash"), joka aristokraattisen etelän arvojärjestyksessä vertautui afrikkalaisiin orjiin tai piirun verran korkeammalle; hänen esi-isänsä oli tiettävästi laivattu Jamestowniin suoraan jostakin Lontoon vankilasta (AAS, 179). Alkuteksti nimeää Old Baileyn (AAE, 222). Kertomus on varsin toisenlainen kuin se, joka seuraa pyhiinvaeltajaisien ("The Pilgrim Fathers") urhoollista rantautumista Plymouthiin vuonna 1620. Istuessaan muutaman kuukauden koulussa hän kuulee paikasta nimeltä Länsi-Intia, minne köyhät miehet matkustavat laivoilla ja rikastuvat (AAS, 194; AAE, 242). Tämä on juuri se sama houkutin, joka sai englantilaiset seikkailijat liikkeelle kotisaareltaan luodakseen perustaa omalle vauraudelleen ja sosiaaliselle nousulle.

Sutpenin tarinassa seuraa nyt aukko. Seuraavaksi lukija saa tietää, että jo kaksikym- 
menvuotias Sutpen on Haitin saarella; hänestä on tullut ranskalaisen sokeriplantaasin tilanhoitaja; hän on oppinut ranskan kielen ja kyyristelee ikkunan vieressä laukoen musketteja pimeyteen, jossa kapinaan nousseet orjat uhkaavat taloon linnoittautuneita ja ovat sytyttäneet sokeriruokopellot tuleen (AAS, 197-199; AAE, 246-248). Kyse on muutaman rivin muistikuvista, ja taas kerronta katkeaa jatkuakseen vasta kolmekymmentä vuotta myöhemmin Sutpenin kertoessa Quentinin isoisälle suunnitelmastaan ja unelmastaan nousta Etelän suurimmaksi plantaasinomistajaksi: hänen aikeensa on perustaa oma dynastia ja saada poika jatkamaan sukua (AAS, 210-211; AAE, 263-264).

Suunnitelma kariutuu ensimmäisen kerran Sutpenin saadessa tietää, että hänen Haitilla naimansa ranskalaisen plantaasinomistajan tyttäressä on ripaus neekeriverta. Nainen on yksikahdeksasosa-perimältään musta eli "octoroon". Sutpen hylkää vaimonsa, jonka nimeä ei romaanissa mainita; romaanin lopussa olevassa henkilöluettelossa hän saa nimen Eulalia Bon. Jätettyään tämän ja avioliitosta syntyneen poikansa Charles Bonin New Orleansiin hän aloittaa tyhjästä Jeffersonissa. Hän menee uudelleen naimisiin perimältään "puhtaan" naisen kanssa ja saa tämän kanssa tyttären Judithin ja pojan Henryn. Sutpenin suunnitelma romuttuu toisen kerran, kun Henry Sutpen ampuu velipuolensa Charles Bonin estäk̈kseen tämän menemästä naimisiin sisarensa kanssa. Kyse olisi ollut samanaikaisesti kahden vahvan tabun rikkomisesta: mustan ja valkoisen rodun sekoittumisesta mutta samalla myös insestistä. Henry Sutpenista tulee henkipatto, ja hän häviää kertomuksesta joksikin aikaa. Sutpen yrittää vielä kolmannen kerran: hän viettelee maillaan asuvan köyhän maajussin tyttären, mutta hylkää tämän oitis, kun joutuu toteamaan, että syntynyt lapsi on tyttö eikä poika. Tyttären isä tappaa Sutpenin viikatteella.

Thomas Sutpenin suunnitelma on ikään kuin tuhoon tuomittu alusta lähtien: hänen haitilainen menneisyytensä tunkeutuu hänen nykyisyyteensä. Hän yrittää kätkeä koloniaalisen menneisyytensä jättämällä ensimmäisen vaimonsa ja poikansa New Orleansiin, mutta menneisyys nousee torjuttunakin ja hyvin konkreettisesti esiin Charles Bonin hahmossa, joka kiihkeästi haluaa, että hänen isänsä tunnustaisi hänet pojakseen. Charles Bonin äiti, lähestulkoon nimetön ja taustaton "kahdeksasaosaneekeri", on Faulknerin versio Charlotte Brontën Bertha Masonista, jonka Mr. Rochester tuo mukanaan Karibialta Englantiin ja sulkee kartanonsa ullakkohuoneeseen. Tämä on juuri se "hullu nainen ullakolla", jonka Sandra Gilbert ja Susan Gubar tunnetussa tutkimuksessaan identifioivat Charlotte Brontën projisoiduksi omakuvaksi ja josta Gayatri Chakravorty Spivak veti tärkeät johtopäätöksensä valkoisen eurooppalaisen naissubjektin syntymisen ehdoista (Gilbert \& Gubar 1979/1984; Spivak 1989).

Charlotte Brontën ja Jean Rhysin "valkoisen kreoli" vertautuu Faulknerin taustattomaan kahdeksasosakreoliin, ja Bertha Masonin oletettu "hulluus" kätkeytyy lähestulkoon yhtä huolellisesti kuin Thomas Sutpenin ensimmäisen vaimon "neekeriys", sillä 
ulkoisesti hän olisi käynyt valkoisesta. Kun Jean Rhys antaa äänen Bertha Masonille romaanissa Siintää saaristomeri, Faulknerilla hänen vastinparinsa jää vaille ääntä.

\section{Koloniaalinen gotiikka, epistemologinen epävarmuus ja manikealainen kuvasto}

Koloniaalinen tausta kummittelee kaikissa kolmessa romaanissa Kotiopettajattaren romaani, Siintää saaristomeri ja Absalom, Absalom!. Hiukan tosin sanoen tämän voi identifioida koloniaalisen tai imperiaalisen gotiikan nimikkeellä (Punter \& Byron, 2004, 44-49). Yksi keskeinen topos gotiikassa ja myös koloniaalisessa gotiikassa on luonnollisesti sukutalo tai kartano, joka pitää sisällään jotain salaisuutta ja joka monesti tuhoutuu tulipalossa. ${ }^{5}$ Faulknerilla Sutpen's Hundred häviää liekkeihin, kun kirjan lopussa Quentin Compson ja Rosa Coldfield lähtevät hakemaan siellä piileskelevää Henry Sutpenia, jolloin Clytie Sutpen eli Thomas Sutpenin neekeriorjan kanssa saama tytär sytyttää talon palamaan. Koloniaalinen menneisyys ei pelkästään palaudu aaveina tai kummituksina, jotka seuraavat päähenkilöitä, vaan se merkitsee sanamukaisesti koloniaalisella riistolla kootun omaisuuden tuhoutumista. Faulknerilla tuhon aavemaisuutta lisää vielä talossa piileskelleen idioottipojan lohduton huuto - poika on Charles Bonin pojanpoika, joka siis Thomas Sutpenista laskettuna edustaa jo neljättä sukupolvea, joka itsepintaisesti kummittelee talossa ja sen palaneissa raunioissa.

Sama koloniaaliseen taustaan kiinnittyvä talo ja sen tuhoutuminen toistuu Jean Rhysilla ja Charlotte Brontëlla. Siintää Saaristomeri -romaanissa vihastuneet entiset orjat polttavat Antoinetten kotitalon, mikä on osasyynä hänen äitinsä Annetten, joka tunnetaan myös nimellä Bertha, hermoromahdukseen. Antoinetten äidin kohtalo luonnollisesti ennakoi ajatusta Antoinettesta / Bertha Masonista mielipuolena, joka Kotiopettajattaren romaanissa sytyttää Rochsesterin Thornfield Hallin palamaan. Kuten Wilson Harris on esittänyt, Rhysin romaanin tuli-motiivi kuvittaa elimellisesti Karibian kolonisointia ja sen orjuuden perintöä arawakien ja karibien ikivanhassa myytissä maan ja taivaan luomisesta (Harris 1983, 49-54). Yliluonnolliset tapahtumat ja magia, kuten voodoo ja obeah-rituaalit, antavat muutenkin leimansa Jean Rhysin romaanin ilmapiirille, joka valmistelee Bertha Masonin "hulluutta" Charlotte Brontëlla ja oikeuttaa Rochsterin pakkotoimet kreolivaimoaan kohtaan. Kun Jean Rhys hahmottelee Antoinettelle nimettömän ja varjomaisen aviomiehen, joka Charlotte Brontëlla on muotoutunut Rochesteriksi, lukija voi helposti nähdä Rochsterin koloniaalisen gotiikan kehyksessä. Syntyy sankari, joka on kartuttanut omaisuuttaan Karibialla ja joka sulkee kreolivaimonsa mielipuolisuuden varjolla Thornfield Hallin ullakolle.

Charlotte Brontën Rochesterin tausta on Karibian osalta yhtä aukkoinen kuin Faulknerin Thomas Sutpenin, ja kummallakin joskin Rochesterilla vähemmän korostuvat gotiikan arkkihirviön piirteet. Erityisesti Rosa Coldfield demonisoi Sutpenia ja kut- 
suu tätä hirviöksi (AAS, 10-12, 17; AAE, 13-15, 23). Lisäksi sekä Absalom, Absalom! että Kotiopettajattaren romaani käsittelevät gotiikalle ominaisia tabuja ja normatiivisen seksuaalisuuden ylittäviä asetelmia: rotujen sekoittumista, insestiä, homoseksuaalisuutta, hulluutta (ks. Sage 1990, 12-17). Faulknerin romaanissa keskeinen tapahtumaketju liittyy juuri Charles Bonin, Henry Sutpenin ja Judith Sutpenin kolmiodraamaan, jossa yhdistyvät sukurutsa eli Charles Bon on aikeissa naida sisarpuolensa, homoseksuaalisuus eli Charles Bonin ja Henry Sutpenin välinen homoeroottinen jännite, jonka välittäjänä toimii heidän sisarensa sekä rotusekoitus eli Charles Bon ei ole sataprosenttisesti "valkoinen", koska hänen äitinsä on "octoroon". Homoeroottinen jännite toistuu Quentin Compsonin ja Shreve McCannonin välillä, kun he rekonstruoivat yli puolivuosisataa sitten tapahtunutta draamaa (Ks. Irving 1975/1977, 77-78; Peterson 2004, 227-265). Painotetusti voi vielä todeta, että juuri rotusekoitus on se kulttuurinen tabu ja mentaalinen hirviömäisyys, joka leimaa kokonaisuudessaan Absalom, Absalomia! ja joka viime kädessä kaataa Thomas Sutpenin suunnitelmat sukunsa jatkuvuudesta. Charlotte Brontën Rochesterilla goottilaisen kartanonherran hirviömäisyys on hillitympää ja viktoriaanista, mutta senkin taustalla kummittelee epäilys entisen vaimon arveluttavasta perimästä sekä viime hetkellä esille noussut syytös kaksinnaimisesta. Ja kun Thomas Sutpen kohtaa loppunsa uskollisen ja köyhän maajussinsa viikatteesta, Rochesterkin saa maksaa rikoksistaan: hän menettää joksikin aikaa näkönsä. Seikan voi tulkita symbolisena kastraationa. ${ }^{6}$

Maantieteellisesti ja historiallisesti Länsi-Intia tai Karibia linkittyy luontevasti Faulknerin missisippiläisen plantaasinomistajan vaurauden ponnahduslaudaksi. Haluan kuitenkin vielä laajentaa tämän koloniaalisen aspektin kosketuspintaa ja yleisyyttä tarkastelemalla eräitä yksityiskohtia, jotka kulkevat rinnakkain Faulknerin Absalom, Absalomissa! ja Joseph Conradin Pimeyden sydämessä. Rajoitan huomioni kerronnallisiin ratkaisuihin, keskushenkilöiden samankaltaisuuteen sekä eräisiin tropologisen rakenteen yhtäläisyyksiin.

Kuten tunnettua, Pimeyden sydämen kerrontastrategia on epäsuora, asian ydintä kiertelevä ja kaarteleva, etäännytetty: nimetön kertoja kuuntelee ja välittää lukijalle sen, mitä Charles Marlow kertoo tälle ja parille muulle veneessä, joka kelluu Thames-joen suulla odottamassa vuoroveden vaihtumista. Marlowen kertomuksen keskiössä on Mr. Kurtz, salaperäinen hahmo, joka Thomas Sutpenin tapaan on "läsnä" tai paikalla vain muutaman sivun verran. Kerronnallisesti "pimeyden ytimeen" eli jokivartta ylöspäin Afrikan viidakoiden keskiöön on kuljettava hitaasti, vaikka heti Conradin kertomuksen alussa Marlowe tuo ilmi, että sama "pimeyden sydän" oli myös Thames-joen suulla, kun roomalaiset yrittivät tunkeutua heille vihamieliseen ja vaaroja täynnä olevaan maahan. Hän toteaa: "Varmaan heitä kuoli täällä kuin kärpäsiä" (PS, 11; HD, 56). Marlowen kerronta paikantuu Lontoon edustalle, Afrikasta etäännytettynä, samoin 
kuin Quentin Compsonin kertomus tapahtuu harvardilaisessa opiskelija-asunnossa, kaukana Mississippistä. Sekä Faulknerilla että Conradilla kerronta lähestyy verkkaisesti ja viipyillen kerronnan keskustaa, jotakin arvoitusta tai salaisuutta tai tietoa, joka on oikeastaan liian kauhistuttava suoraan artikuloitavaksi. "Pimeyden sydämestä" on kerronnallisesti palattava nykyhetkeen, mutta kummassakin tekstissä sulkeuma jää osittaiseksi ja monimieliseksi: Marlowe katsoo parhaaksi väärentää totuutta, kun hän paljastaa Mr. Kurtzin viimeiset sanat tämän rakastelulle. Hän sanoo, että Kurtz oli viimeisenä hengenvetonaan lausunut naisen nimen . Todellisuudessa mieleltään järkkynyt Kurtz kuiskaa: "Kauhu, kauhu!" (PS, 143, 159; HD, 149, 161). Quentin Compson puolestaan on psyykkisessä kaaoksessa lopettaessaan kertomuksensa, ja kuten tiedämme Ä̈̈ni ja vimma -romaanin kautta, hän päätyy melko pian tämän jälkeen itsemurhaan. Vaikka Ä̈̈nessä ja vimmassa Quentinin itsemurhan todennäköinen selittäjä on hänen kuviteltu insestinen suhteensa sisareensa, Absalom, Absalomissa! Quentinia ja Henry Sutpenia, johon Quentin voimakkaasti samastuu, järkyttää sukurutsaakin enemmän verensekoitus eli ajatus valkoisen ja mustan rodun sekoittumisesta.

Sekä Conradin Pimeyden sydämen että Faulknerin Absalom, Absalomin! kerrontaa leimaa epistemologinen epävarmuus. Piirre on ominainen klassisen goottilaisen romaanin tai monimielisen ("ambiguous") gotiikan edustajille (ks. Savolainen 1992, 20-21). Ajatellaan vain Mary Shelleyn Frankensteinia (1818), jonka kerronta rakentuu sisäkkäisistä narratiiveista ja joiden keskiössä on Viktor Frankensteinin luoman hirviön oma kertomus. Toisen samankaltaisen esimerkin tarjoaa Bram Stokerin Dracula (1897), joka koostuu eri henkilöiden muistiinpanoista, päiväkirjoista ja kirjeistä, joissa Kreivi Dracula on lukemattomien arvailujen, spekulaatioiden ja tieteellisten päätelmien kohteena, mutta joissa Kreivillä itsellään ei ole omaa ääntä.

Sekä Thomas Sutpen että Mr. Kurtz ovat kumpikin äärimmäisyyksien ihmisiä, omien pakkomielteenomaisten suunnitelmiensa toteuttajia, häikäilemättömyydessään ja demonisuudessaan toistensa kaltaisia. Edellä viittaisin Thomas Sutpenin taustaan, joka paikansi hänet Etelän yhteiskunnan alapäähän, valkoiseen roskaväkeen. Kurtzistakin vihjataan, että hän kuului köyhälistöön tai että hän ei ollut eräiden mielestä tarpeeksi varakas kihlautumaan englannittarensa kanssa (PS, 156; HD, 159). Kummallakin miehellä toiminnan tähtäimenä oli sosiaalinen nousu, vauraus ja valta. Ne perustuivat puuvillaan tai kumiin ja norsunluuhun. Molemmat päätyivät käyttämään pyrkimyksissään "epäterveitä" ("unsound") menetelmiä (PS, 128; HD, 137-138). Yli-ihmismäisessä uhmassaan kumpikin astuu ihmisyyden rajalle ja tuhoutuu. Mr. Kurtz taantuu mielipuolisuuteen, jossa hän saattaa ratkaista häntä jonkinlaisena jumalana pitävien alkuasukkaiden hengen silmääkään räpäyttämättä: ”Hävittäkää kaikki pedot” (PS, 103), ”Exterminate all the brutes!" (HD, 118). Quentinin kuvitelmissa Thomas Sutpen luo plantaasinsa jumalallisella mahtikäskyllä "Tulkoon Sutpen’s Hundred, niin kuin muinoin 
Tulkoon valkeus" (AAS, 6). Hänen sanansa on laki plantaasin rajaamalla alueella, ja hän käyttää häikäilemättömästi hyväkseen suunnitelmansa toteuttamiseksi niin mustia kuin valkoisia.

Vielä muutama huomio Conradin ja Faulknerin tekstejä läpäisevästä metaforiikasta tai tropologisesta tasosta, joka tukee koloniaalista luentaani Absalom, Absalomista! Conradin osalta Pimeyden sydämen manikelaiseen järjestelmään (ks. JanMohamed 1985; Fanon 1961/2003) on kiinnitetty huomiota lukemattomia kertoja: pimeys on merkitsijä, joka viittaa yhtä lailla Afrikan mantereen sisäosien salaperäisyyteen ja vaaroihin, villiyteen ja barbariaan Euroopan vastakohtana kuin Mr. Kurtzin mielen "pimeyteen", siihen metafyysiseen kauhuun, joka lopulta tuhoaa hänet. Kuten jo edellä mainitsin, on tärkeää huomata, että heti tekstin alussa Marlow siirtää pimeyden, kuoleman ja kauhun teemat Thames-joen rantatörmille. Ja kun Marlow menee tapaamaan Kurtzin kihlattua Lontoossa ja palauttaa pinkan tälle osoitettuja kirjeitä, kohtaus tapahtuu hämärässä huoneessa ja keskustelun aikana pimeys tihenee (PS, 153-157; HD, 156-159). Faulknerin romaanista löytyy samankaltainen metaforinen rakenne: Romaani alkaa pimeässä ja tunkkaisessa, ikkunaluukuin suljetussa huoneessa Jeffersonissa, jossa Rosa Coldfield alkaa versionsa Thomas Sutpenista Quentin Compsonille. Samoin romaani päättyy pimeässä makuukamarissa, jossa Quentin ja hänen kanadalainen toverinsa ovat setvineet Thomas Sutpenin arvoitusta. Shreve McCannon kysyy: "Miksi vihaat etelää?", johon Quentin vastaa liian nopeasti: "En vihaa sitä". "En vihaa sitä, hän ajatteli huohottaen kylmässä ilmassa, uuden Englannin koleassa pimeydessä.” (AAS, 301; AAE, 378.)

Lähemmässä tarkastelussa eräät muutkin yksityiskohdat alkavat askarruttaa. $\mathrm{Ne}$ houkuttavat miettimään, miksi juuri näin - miksi jokin merkitsijä valikoituu merkityksenkantajaksi muitten joukosta? Huomionarvoista on myös, että molemmat valitsemani esimerkit ovat muistiin piirtyneitä kuvia, ikään kuin pysähtyneitä välähdyksiä. Pimeyden sydämen alkupuolella Marlow kertoo tilanteesta, jossa hän tähyilee laivan kannelta esille nousevaa Afrika rannikkoa. Vaikutelma on ristiriitainen. Rannikko seisoo katsojan edessä yhtäl̈ltä "hymyilevänä" ("smiling"), "synkkänä" ("frowning"), "kutsuvana" ("inviting") ja "uljaana" ("grand"), mutta samanaikaisesti siinä on jotakin "rumaa" ("mean"), "ikävää" ("insipid") tai "villiä" ("savage"). Näkymä on arvoitus. Se kätkee "salaisuuden" ("enigma") (PS, 24-25; HD, 60). Rannikko on "yksitoikkoisen karu" ("an aspect of monotonous grimness") (PS, 25; HD, 60). Rannasta kohoava viidakko on suunnattoman suuri, jättiläismäinen; niin tummanvihreä, että se näyttää lähes mustalta rantaan murtuvien aaltojen yläpuolella: "The edge of a colossal jungle, so dark-green as to be almost black, fringed with white surf; PS, 25; HD, 60, kursivointi M. S.). Toisilleen vastakkaiset määrittäjät sekoittuvat toisiinsa; musta viidakko on valkoisten rantaan murtuvien aaltojen päärmäämä.

Melko pian näiden vaikutelmien jälkeen Marlowe kertoo ranskalaisesta sotalaivas- 
ta, joka ampuu tykeillään viidakkoa; ilmeisesti Ranska kävi sotaa Marlowelle epämääräiseksi jääneen vihollisen kanssa.

Maissa ei näkynyt missään edes katoksen tapaista ja kuitenkin laivasta ammuttiin pensaikkoon.[--] Käsittämätöntä - maan, taivaan ja meren tyhjä äärettömyys ja siinä tuo laiva tulittamassa_maanosaa. Pum! pani jokin kuuden tuuman tykki; pieni liekki leimahti ja katosi, vähäinen valkea savupilvi häipyi; mitättömän kokoinen ammus lensi heikosti ujeltaen - mutta mitään ei tapahtunut. Mitään ei voinut tapahtua. (PS, 26-27, kursivointi M. S.)

There wasn't even a shed there, and she was shelling the bush. [...] In the empty immensity of earth, sky, and water, there she was, incomprehensible, fring into a continent. Pop, would go one of the six-inch guns; a small flame would dart and vanish, a little white smoke would disappear, a tiny projectile would give a feeble screech - and nothing happened. Nothing could happen. (HD, 61-62, kursivointi M. S.)

Viidakko ("jungle") on yllä olevassa katkelmassa kenties hiukan vähättelevästi pusikko tai tiheikkö ("bush"), joskin Afrikassa sana "bush" koodautuu myös "viidakoksi" tai "aarniometsäksi" . Ranskalainen sotalaiva on ankkurissa paikallaan ikään kuin tyhjiössä ("in the empty immensity of earth, sky, and water") tulittamassa maanosaa ("firing into a continent") eikä ammuskelulla ole mitään vaikutusta. Miten ylipäänsä voidaan ampua kokonaista maanosaa? On merkittävää, että ammukset eivät lennä johonkin maaliin ("shooting at") vaan ikään kuin syvälle "pimeyden sydämeen" asti ("firing into"). Voi kuvitella, että samaan tapaan roomalaiset aikoinaan tähyilivät ja kenties ampuivat nuoliaan Thames-joen rantarytekköihin, jos jatkamme Marlowen käynnistämää analogiaa.

Hämmästyttävän samanlainen metaforinen rakenne toimii Absalom, Absalomissa!. Tällaiset ovat ne muutamat rivit, joissa kerrotaan Thomas Sutpenista puolustamassa Haitin saarella isäntänsä taloa ja tämän perhettä sokeriruokopeltojen palaessa heidän ympärillään. Kuva raamittuu samanlaiseen tyhjyyden ja mittaamattomuuden tilaan kuin ranskalainen sotalaiva Afrikan rannikolla. Faulknerilla Haiti on

[--] pieni syrjäinen saari vuorottelevan päivän ja yön kuvun alla kuin tyhjiössä, johon ei mikään apu voinut tulla [--]. [Sisällä talossa Thomas Sutpen ja plantaasin omistaja] laukoivat, ei vihollista vaan Haitin yötä kohti, näpäyttelivät vähäisiä turhia välähdyksiä hautovaan ja veren kyllästämään ja sykkivään pimeyteen. (AAS, 202-203, lisäys M. S.)

[--] the little lost island beneath its down-cupped bowl of alternating day and night like a vacuum into which no help could come [--]. [Thomas Sutpen and the master of the plantation] fired at no enemy but Haitian night itself, lancing their little vain and puny flashes into the brooding and blood-weary and trobbing darkness. (AAE, 253, lisäys ja kursivointi M. S.) 
Tässä on huomionarvoista, että puolustajat eivät ammu musketeillaan ketään erityisesti ("fired at no enemy") vaan haitilaista yötä; viime kädessä he ammuskelevat varsin tehottomasti pimeyteen ("into the [--] darkness"). Sekä Faulknerilla että Conradilla, jälkimmäisellä metaforisella tasolla, Haiti ja laajemmin Länsi-Intia sekä Afrikan manner ovat epämääräistä, kasvotonta, hallitsematonta kaaosta ja pimeyttä.

\section{Absalom, Absalom!, Santo Domingon kapina ja historia}

Jos Faulkerin Absalom, Absalomia! haluaa lukea kolonialismin näkökulmasta, on syytä lähteä liikkeelle Karibialta. Manikelainen koneisto toistaa ja muokkaa maailman hahmottamista, mutta se myös sekoittaa polarisoituneita ääripäitä pimeys-valo, yö-päivä, musta-valkoinen, kaaos-järjestys, barbaarinen-sivistynyt, suljettu-avoin. Haitin saari on maantieteellisestikin sijainniltaan tärkeä; Faulknerin sanoin se on "puolivälissä sitä mitä nimitämme viidakoksi ja sitä mitä sanomme sivistykseksi” (AAS, 200), "the halfway point between what we call the jungle and what we call civilization" (AAE 250). Maaperässään se kantaa "kahdensadan vuoden sortojärjestelmän" jälkiä (AAS, 201), "two hundred years of oppression and exploitation" (AAE, 251). Vaikka saarella puhuttu ranska luonnollisesti edustaa sivistystä, Yoknapatawhan piirikunnan ja jeffersonilaisten näkökulmasta sekin signifioi vierautta ja käsittämättömyyttä - etenkin kun Sutpenin mukanaan tuomat orjat puhuivat keskenään samoin kuin isäntänsä kanssa "eräänlaista ranskaa", jota aluksi luultiin jonkinlaiseksi "hämäräksi ja pelottavaksi alkuasukkaiden kieleksi” (AAS, 28; AAE, 36). On merkittävää, että Sutpenin orjat eläimellistetään täysin; he työskentelivät "aivan kuin neekerit olisivat ollet juhtia" (AAS, 28), "as if the negroes actually were wild men" (AAE, 37), "ilkosen alastomina, verhonaan vain ihoa peittävä kerros kuivunutta mutaa" (AAS, 27), "stark naked save for a coating of dried mud" (AAE, 35). Toiseudessaan he eroavat niistä mustista orjista, joihin jeffersonilaiset olivat tottuneet ja jotka olivat hyväksyttävä osa Etelän yhteiskuntaa ja maailmanjärjestystä. Sutpenin mustat olennot vertautuvat niihin nimettömiin ja kasvottomiin afrikkalaisiin, jotka Marlowe löytää Mr. Kurtzin asemalta "pimeyden sydämestä". "Pimeyden sydän" sijoittuu Afrikkaan, mutta se kulkeutuu Sutpenin ja tämän neekeriorjien mukana myös Mississippiin.

Miten on selitettävissä, että Faulkner muuntaa ilmeisen tietoisesti historiallista totuutta sijoittamalla Thomas Sutpenin Haitille ja kuitenkin samalla unohtaa, että Haiti julistautui itsenäiseksi Jean Jacques Dessalines' in johdolla 1804 ja että ne orjat, jotka Sutpen toi mukanaan Jeffersoniin, olivat historiallisessa katsannossa vapaita? Miten on mahdollista, että Faulkner kirjoittaa historiaa oman päänsä mukaan ikään kuin Touissant L'Ouverturen johtamaa Santo Domingon vallankumousta (1791-1804) ei olisi koskaan tapahtunut? (Ks. James 1938/2001.) Richard Goddenin mukaan Faulknerin historian väärennys on palvellut tiettyä tarkoitusta: Faulkner tarvitsee Thomas Sutpenin 
kaltaisen ylivertaisen plantaasiluokan edustajan, jotta valkoisen rodun ylivaltaa ("white supremacy”) mustaan nähden voidaan ylläpitää ja vahvistaa. Faulkner ikään kuin kiertää sen mahdollisuuden, että etelän plantaasinomistajien olisi pitänyt vakavasti nähdä orjansa "mustina jakobiineina", koska tämä olisi tehnyt heistä aktiivisia toimijoita ja näin ollen potentiaalisia kapinoitsijoita (ks. Godden, 1994).

Historiallisella Santo Domingon vallankumouksella oli kauaskantoisia vaikutuksia Yhdysvaltain etelävaltioissa siinä mielessä, että 1790-luvulta eteenpäin orjakapinoiden uhka oli jatkuvasti olemassa. Yhdysvaltain suurin orjakapina syttyi Lousianassa 1811; muita laajuudeltaan pienempiä kapinoita tai kapinayrityksiä olivat Gabriel Prosserin käynnistämä Virginiassa 1800, Denmark Veseyn suunnittelema Etelä-Carolinassa 1822 sekä Nat Turnerin johtama Virginiassa 1831 (Genovese 1979/1981, 1-51). ${ }^{8}$ On merkillepantavaa, että kun Mr. Compson kertoo Sutpenista pojalleen Quentinille 1835, tämä tapahtuu neljä vuotta historiallisen Nat Turnerin kapinan jälkeen. Myös kapinoivat orjat olivat tietoisia Karibian tilanteesta: sekä Gabriel Prosser että Denmark Vesey näkivät Santo Domingon/Haitin tapahtumat kutsuna ja rohkaisuna toimintaan - Haitista toivottiin saatavan apua tai uskottiin, että vastaperustettu tasavalta tarjosi mahdollisen turvapaikan kapinan epäonnistuessa (Genevese 1979/1981, 48-49, 9596). Kukaan Absalom, Absalomin! kertojista ei myöskään tunnu olevan tietoinen karanneiden orjien muodostamista yhteisöistä ("maroon communities"), joita oli muiden muassa Floridassa ja Etelä-Carolinassa (Genovese 1979/1981, 42; 58; 68). Yhteisöt tarjosivat turvapaikan karanneille orjille samalla kun ne toimivat tukikohtina, joista käsin voitiin ahdistella valkoisia siirtokuntia.

Siinä missä Richard Godden näkee "unohdetun" historian tarkoitushakuisena reaktiona etelän kokemaan orjien kapinoinnin uhkaan, John T. Matthews nostaa vakuuttavasti esiin Etelään kohdistuvan kolonisaation kaikessa laajuudessaan. Thomas Sutpen huijaa pilkkahinnalla chickasaw-intiaaneilta plantaasinsa maa-alan ja hankkii neekeriorjansa laittomalla Länsi-Intian orjakaupalla, sillä Yhdysvallat ja Englanti kielsivät orjakaupan 1807. Hän käyttää häikäilemättömästi kaikkia, niin mustia kuin valkoisia, oman päämääränsä saavuttamiseksi. Länsi-Intia nousee avainasemaan Sutpenin suunnitelman toteuttamisessa. Se on keskeinen sekä työn organisoimisessa eli sokeriruokoviljelmien muuttamisessa puuvillaplantaasiksi että elämäntavassa, kun Sutpen nousee plantaasinomistajaksi (ks. Matthews 2004, 255-257). Matthews argumentoi, että Absalom, Absalomin! eri kertojat kiertävät historiallisia tosiseikkoja, jotka he voisivat myöntää suoraan: esimerkiksi kun Quentin kuvailee Karibialla tapahtunutta orjakapinaa, hän ei, niin kuin ei Sutpenkaan, kertaakaan käytä nimitystä "orja" - sen sijaan mustia sokeriruokopelloilla työskenteleviä kutsutaan "nekruiksi" ("niggers"). Ja kun romaanissa Haitiin viitataan nimityksellä "menetetty saari", "the little lost island" (AAE, 253), tämä oli juuri se nimitys, jolla Haiti tunnettiin Etelän orjanomistajien 
keskuudessa 1800-luvulla. (Ibid. 252, 254.) Karibialta kantautuvat tiedot herättivät pelkoa ja pitivät valkoisia jatkuvassa epävarmuuden tilassa, mutta Yoknapawtaphan piirikunnassa merentakaisista huhuista ei tahdota tietää mitään.

\section{Jälkikoloniaalisen luennan rajoista}

Olen lukenut spekulatiivisesti, rinnakkain ja ristiin Faulkneria ja Conradia nostaakseni esiin Absalom, Absalomin yhden koloniaalisen juonteen ja nyt on aika palata kysymykseeni koloniaalisen luennan rajoista. Minua mietityttää se, miten parin viime vuosikymmenen aikana "koloniaalisesta" ja "jälkikoloniaalisesta" on tullut käsitteitä ja iskusanoja, joita voi käyttää lähestulkoon mistä tahansa dominoinnista, alistamisesta, hyväksikäytöstä ja hiljentämisestä (ks. esim. Parry 1987; Ahmad 1992/2000). Jos käsitteen semanttinen kenttä laajenee, se pahimmillaan myös väljenee ja hämärtyy, ja voi lopulta johtaa yllättäviin ja arveluttaviin päätelmiin.

Tutkimuksessaan William Faulkner's Postcolonial South (2000) Charles Baker argumentoi, että Faulknerin tuotanto on jälkikoloniaalista ja että yleisemminkin etelävaltioiden kirjallisuuden renessanssi 1920-luvulta 50-luvulle on nähtävä reaktiona pohjoisvaltioiden harjoittamaa kolonialismia vastaan. Sisällissota (1861-1865) päättyi etelävaltioiden häviöön ja sitä seuranneena jälleenrakennuksen kautena 1865-1877 Pohjoinen itse asiassa dominoi, hyväksikäytti ja alisti lyötyä Etelää - näin ollen Bakerin mukaan Faulknerin sisällissodan jälkeisestä Etelästä tulee kolonisoitu maa-alue.

Baker luonnollisesti tiedostaa sen kolonialismin, joka on ratkaisevasti vaikuttanut Yhdysvaltojen muotoutumiseen kansakuntana - maan valloittaminen ja riistäminen mantereen alkuperäisasukkailta sekä orjuusinstituutio - mutta nämä näyttäytyvät Bakerille Pohjois-Etelä -astelmassa sortona sorron sisällä: Sutpen keinottelee maansa intiaaneilta vain menettääkseen sen pohjoisvaltioiden rahamiehille ja keinottelijoille jälleenrakentamisen ja sitä seuraavina vuosikymmeninä (Baker 2000, 71). Mielestäni on oireellista, että vaikka Baker viittaakin lyhyesti Michael Millgatin kautta Mr. Rochesterin ja Thomas Sutpenin väliseen yhtäläisyyteen eli siihen, että kummankin ensimmäinen vaimo tulee Länsi-Intiasta (Baker 2000, 69-70), hän ei osoita Sutpenin Haitin kauden ratkaisevaa merkitystä sen pääoman hankkimisessa, joka teki mahdolliseksi Sutpen's Hundred -plantaasin perustamisen Jeffersonin ulkopuolelle. Bakerin tutkimuksessa Faulkner vertautuu tuon tuostakin sellaisiin antikolonialistisiin tai jälkikoloniaalisiin kirjailijoihin, kuten Chinua Achebe, Ngugi wa Thiong'o ja William Butler Yeats. Baker kyllä myöntää Faulknerin etuoikeutetun aseman valkoisena miehenä, mutta silti hän katsoo mahdolliseksi käyttää hänestä termiä "subaltern" suhteessa pohjoisvaltioihin. Itse asiassa Baker joutuu tuon tuostakin esittämään varauksia ja väistöliikkeitä tämän argumenttinsa tueksi (ks. esim. Baker 2000, 41, 48, 63, 68), minkä olen taipuvainen tulkitsemaan oireena siitä, että argumentti on alun alkuaan hatara. 
Mielestäni Bakerin argumentaation heikoin kohta on siinä, että Baker operoi Antonio Gramscin termillä "subaltern" tai alistetut ryhmät hyvin väljästi ja epäspesifisti. Bakerin $(2003,3)$ määrittelyn mukaan "subaltern" teknisesti tarkoittaa sotilasarvoltaan alempaa jalkaväensotilasta ("an inferior foot soldier"), mutta hän saman tien lisää, että termi on alkanut tarkoittaa kaikkia alistettuja ryhmiä ("all oppressed groups"). Bakerin määrittely on pahasta vesittynyt. On huomionarvoista, että Baker ei missään yhteydessä suoraan viittaa Gramsciin, eikä Gramscia löydy myöskään hänen lähdeluettelostaan. Gramscille ”subaltern" tai alistetut ryhmät olivat niitä, joilla ei ollut pääsyä hegemoniseen kulttuuriin - käsittääkseni Gramsci ajatteli erityisesti köyhiä talonpoikia ja työläisiä, ja erityisesti niitä, jotka jäivät "virallisen” kulttuurin ja poliittisen toiminnan ulkopuolelle. Italian kontekstissa näitä ryhmiä olivat mm. Etelä-Italian maattomat talonpojat ja maalaisväestö ylimalkaan vastakohtana Pohjois-Italian urbaanille työväestölle: kyse on nimenomaan niistä prosesseista, joiden kautta alistetut voivat muodostua poliittisiksi ja kulttuurisiksi toimijoiksi (ks. Gramsci 1971, 52-60, 69-76). Termi on joka tapauksessa ollut 2000-luvun alussa voimakkaan kiinnostuksen kohteena historian- ja politiikantutkijoiden keskuudessa, ja Italiasta ja Euroopasta irrotettuna sitä on käytetty mm. Meksikon Zapatista-liikkeen samoin kuin Intian köyhien maalaisten ja heimolaisten toimijuuden analysoimisessa. ${ }^{9}$ Intiassa ja Englannissa toimineen Subaltern Studies -ryhmän työssä ja siitä innoitusta saaneella Gayatri Chakravorty Spivakilla termillä on varsin toisenlainen sisältö kuin Bakerilla (Spivak 1987/1988, 191-221; 1995, ix-xxix). Baker venyttää termiä siinä määrin, että koko ajatus alistetuista trivialisoituu. Mitä tarkoittaisi kysymys "Can the Subaltern Speak?” Faulknerin kohdalla (ks. Spivak 1988, 271-313)?

Ainakaan pohjoisvaltiolaiset kustantajat eivät estäneet vielä tuntematonta kirjailijaa saamasta ääntään kuuluviin: Faulknerin ensimmäisen runokokoelman The_Marble Faun (1924) julkaisi bostonilainen kustantaja ja ensimmäisen romaanin Soldiers' Pay (1926) painoi newyorkilainen kustantamo. Pikemminkin Faulknerin kotikaupunki vierasti omaa kirjailijaansa, mutta kun Faulknerista kiinnostuivat Ranskassa 1930-luvulla muiden muassa André Malraux ja Jean-Paul Sartre, kukaan ei voinut enää epäillä Faulknerin painoarvoa Yhdysvalloissa ja tie kansainväliseen kuuluisuuteen oli auki. On totta, että valtaosassa tuotantoaan Faulkner käsittelee tai sivuaa vanhan Etelän ja sen ihanteiden katoamista ja sisällissodan aiheuttamaa traumaa. Näin on teoksissa The Sound and the Fury, Absalom, Absalom! ja Go Down, Moses (1942), mutta kyse on myös modernin maailman tunkeutumisesta Etelään, kuten teoksissa Pylon (1935), The Hamlet (1940), The Town (1957) ja The Mansion (1959).

Kyse ei ole kenties niinkään siitä, että modernin tuloa sellaisenaan vierastettiin, vaan siitä, että moderni maailma assosioitui voimakkaasti Pohjoisen ylhäältäpäin annettuun ohjailuun ja pakkotoimiin, kuten teollistumiseen, kaupungistumiseen ja talo- 
udelliseen hyväksikäyttöön, sisällissodan jälkeisinä vuosikymmeninä. Tämän ohjailun ja pakkotoimien jälkivaikutuksia voi nähdä vielä siinä tavassa, jolla Nashvillen Agraarikot määrittelivät Etelän "traditionaalista" ominaislaatua suhteessa Pohjoisen moderniin ja "edistykselliseen" elämäntapaan artikkelikokoelmassa I'll Take My Stand (1930), mutta Faulkner ei osallistunut ryhmän toimintaan ja muutoinkin läpi koko uransa säilytti yksityisyytensä suhteessa Etelää koskeviin yhteiskunnallisiin kysymyksiin. Vaikka historiallisesti ajatellen suhteellisen vähälukuinen herrasmies-aristokratia menettikin eniten sisällissodassa ja jälleenrakennuksen kautena (Baker 2000, 22), tämä ei nähdäkseni oikeuta analysoimaan heidän tilannettaan alistettuina gramscilaisessa mielessä. Jos valkoiset aristokraattisen taustan omaavat ja ylempään keskiluokkaan kuuluvat valkoiset miehet ovat samalla lähtöviivalla kuin Etelän valkoiset köyhät ("white trash") tai afrikkalaisamerikkalaiset, tällöin analyyttistä ajattelua jäsentävä teoria ei toimi. ${ }^{10} \mathrm{Ba}$ ker universalisoi alistamisen, kärsimyksen ja hiljentämiseen niin, ettei se enää merkitse mitään.

Bakerin argumentoinnissa on monia muitakin kohtia, joita on syytä arvioida kriittisesti. Yksi on tietysti se, missä mär̈in on ylipäänsä oikeutettua puhua Yhdysvaltain pohjoisvaltioiden suhteesta etelävaltioihin kolonialismin ja imperialismin käsittein. Selvästikään kolonisaatio ja imperiaaliset pyrkimykset eivät yksinomaan kohdistu eri "rotua" edustaviin, joskin "rodullistamista" voidaan käyttää yhtenä kolonisaation oikeuttajana, kuten esimerkiksi Englanti rodullisti irlantilaiset (Baker 2000, 16-19). Vaikka H. L. Menchen vielä vuonna 1920 tunnetusti valitti Etelän kulttuurista takapajuisuutta ja vihjaili myös etelävaltiolaisten rotusekoituksesta (Baker 2000, 25-26), Etelän kirjallinen renessanssi oli jo muotoutumassa. Tämän kirjallisen kukoistuksen (esim. King 1980) voi hyvin tulkita reaktiona Pohjoisen kulttuuriseen dominointiin ja tarpeena määritellä oma "etelävaltiolaisuus", mutta onko mielekästä rinnastaa Nashvillen Agraarikot ja Faulkner Chinua Achebeen ja Ngugi wa Thiong'oon jälkikoloniaalisina kirjailijoina? Baker rinnastaa Faulknerin myös William Butler Yeatsiin, ja tätä asetelmaa voi pitää osuvana, joskaan se ei automaattisesti tee Faulknerista "jälkikoloniaalista" kirjailijaa (Yeatsista, ks. Said 1993, 265-288).

Koko Yhdysvaltain historia on yleisessä mielessä kolonisaation historiaa: laajan mantereen haltuunottoa ja sen alkuperäisasukkaiden alistamista ja tuhoamista, ja tältä osin pohjois- ja etelävaltiot olivat molemmat valloittajia ja kolonisoijia ensimmäisten menestyneiden siirtokuntien perustamisesta lähtien 1600-luvun alusta. Sisällissodan (1861-1865) yhtenä pontimena puolestaan oli juuri yksi "sisäisen" kolonisaation ilmentymä, kysymys orjuudesta, joka jakoi kansakunnan kahtia. Vaikka hyväksyttäisiinkin ajatus, että voitokas Pohjoinen eräässä mielessä "kolonisoi" etelävaltiot eli osin miehitti, hallinnoi, rajoitti oikeuksia ja hyväksikäytti taloudellisesti, virallisesti uudelleenrakentamisen kausi päättyi 1877, jolloin saman logiikan mukaan alkoi Etelän "jäl- 
kikoloniaalinen" vaihe. Etelän taloudellinen, yhteiskunnallinen ja kulttuurinen elpyminen oli hidasta ja se kamppaili edelleenkin monien sisäisten ongelmiensa kanssa (mm. Jim Crow -lait), mutta kun tullaan 1920- ja 1930-luvuille, ainakin kulttuurinen toimijuus oli löytänyt kanavansa ja kirjallinen elinvoima oli palautunut. ${ }^{11}$ Ajatus kolonisaatiosta menettää merkitystään mitä lähemmäksi tullaan nykyaikaa ja on lähestulkoon mieletön Uuden Etelän vahvistuessa toisen maailmansodan jälkeisinä vuosikymmeninä, jolloin Mason-Dixon -linja pohjois- ja etelävaltioita erottavana rajana on enemmän mielikuvitusta kiehtova metafora kuin konkreettinen rajalinja (ks. Gray 1986, 220-231). Voidaan kuitenkin väittää, että eräät "sisäisen" kolonisaation ongelmat eivät ole mihinkään kadonneet. Siitä huolimatta, että 1990-luvun alkupuolelta etelävaltiot ovat nousseet Yhdysvaltain taloudellisen kasvun veturiksi, taloudellinen eriarvoisuus ja vaurauden epätasainen jakautuminen ovat edelleenkin näkyvissä sekä alueellisesti että luokka-aseman ja "rodun” näkökulmasta: kaupungit ovat hyötyneet kun maaseutu on taantunut, ja köyhät valkoiset ja köyhät afrikkalaisamerikkalaiset eivät ole hyötyneet etelän materiaalisesta hyvinvoinnista (ks. Gray 2000, 342-343; 346-349). Mutta onko enää syytä puhua näistä sosiaalisista ongelmista kolonisaation tai jälkikolonialismin termein?

Edellä esittämäni lisäksi Bakerin argumentoinnissa on muitakin ongelmakohtia. Hän selittää hyvin yksioikoisesti afrikkalaisamerikkalaisiin, valkoisiin köyhiin ja naisiin kohdistuvan alistamisen reaktiona Pohjoisen harjoittamiin pakkotoimiin ja kontrollointiin: kyse on siitä että alistetut puolestaan alistavat omia marginaalissa olevia ryhmiään (Baker 2000, 36, 42). Tämän ajatusketjun implisiittinen oletus näyttää olevan, ettei näitä samaisia alistamisen muotoja ollut olemassa ainakaan samassa määrin ennen pohjoisvaltioiden sekaantumista etelävaltioiden asioihin. Samassa päättelyketjussa on myös se ongelma, että "rotuun", luokkaan ja sukupuoleen kohdistuvat alistamisen muodot näyttäytyvät monoliittisesti samanlaisilta; Baker ei viittaa esimerkiksi siihen, miten orjuuden aikana Etelän valkoisen naisen ("southern belle") "puhtaus" tuotettiin mustien naisten seksuaalisella hyväksikäytöllä tai miten valkoiset ja mustat miehet olivat tässä asetelmassa aivan erilaisissa asemissa. Arveluttavana pidän myös sitä, miten Baker liittää Faulknerin teoksissaan esille tuoman kärsimyksen ja kestämisen ("endurance") teemat jälkikolonialisoivaan asenteeseensa: alistettujen kärsivällinen odotus johtaa eräänlaiseen kristillis-metafyysiseen pelastukseen, joka avaa näköalan myös tulevaisuuteen (Baker 2000, 98-99). Tällainen asenne ei ole kaukana uhriksi asettumisesta eikä siihen kuulu aktiivinen toiminta konkreettisten alistamisen ja hiljentämisen muotojen purkamiseksi. Baker lopettaa kirjansa jokseenkin odotetusti Faulknerin ajatukseen kestämisestä kaikesta kivusta, väkivallasta ja virheistä huolimatta, mikä on täysin vastakkainen strategia sellaisille anti- ja jälkikoloniallisille teoreetikoille ja aktivisteille kuin Frantz Fanon ja Albert Memmi. Kumpikin näki dekolonisaatioprosessin väistämättä väkival- 
taisena (Fanon 1961/2003, 33-85; Memmi 1974, 119-141).

Tutkija voi hakea samanlaisuuksia ja analogioita eri ilmiöiden ja tapahtumien analysoimiseksi: kyse on samanlaisuuksien ja analogoiden tuottamisesta heuristisena kokeena, jolloin nähdään auttavatko ne ilmiöiden ja tapahtumien lopullisessa ymmärtämisessä. Kuitenkin lopullisessa tulkinnassa on aina palattava tapahtumien erityisyyteen, siihen spesifiseen kulttuuriseen, sosiaaliseen ja poliittiseen kontekstiin, johon tapahtumat asettuvat. Kyse on viime kädessä siitä, mitä uutta ilmiöstä saadaan esille tarkastelemalla sitä suhteessa muihin samankaltaisiin mutta samalla eri kontekstissa toimiviin tekijöihin. ${ }^{12}$ Tätä taustaa vasten Baker ei mielestäni tuo mitään ratkaisevasti uuttaa Faulkner-tutkimukseen; pikemminkin voi väittää, että hän hämärtää käsitystä siitä mitä jälkikoloniaalisella tutkimuksella on tarjottavana. Kyse ei voi olla vain kärsimyksen, alistamisen ja dominoinnin määrästä vaan myös sen ominaislaadusta ja erityispiirteistä: Faulknerin "alistettuna oleminen" gramscilaisittain mitätöi Etelän todelliset "alistetut" Yoknapatawphan piirikunnassa: intiaanit, afrikkalaisamerikkalaiset ja valkoiset köyhät. ${ }^{13}$ Voisi jopa spekuloida, missä määrin Bakerin teoreettinen liike pyrkii tahtomattaankin vahvistamaan ja palauttamaan valkoista miehistä hegemoniaa trivialisoimalla etelävaltioiden syvään juurtunutta historiallista traumaa: orjuutta ja sen seurausten jälkipuintia.

Operoidessaan "subaltern”-termillä Absalom, Absalomia! tulkitessaan Baker olisi esimerkiksi voinut tarkastella niiden hahmojen funktioita, joilla on monella tasolla alistettu ja hiljennetty asema romaanissa: ajattelen nimetöntä sekaveristä "kahdeksasosaneekeriä”, joka vierailee Sutpens Hundredissa poikansa haudalla, tai Clytie Sutpenia, joka on Thomas Sutpenin ja nimettömän neekerinaisen tytär - Sutpen oli viisaasti sisällyttänyt neekeriorjiensa joukkoon kaksi naista, koska Etelän orjanomistajan tapaan hän saattoi näin kasvattaa pääomaansa. Ulkopuolisena kanadalaisena Shreve McCannon pukee sanoiksi sen, mitä Quentin Compson ei pysty ilmaisemaan. Absalom, Absalomin! lopussa hän otaksuu, että ajan mittaan rotusekoituksen tuloksena syntyneet Jim Bondit valloittavat läntisen pallonpuoliskon (AAS, 300; AAE, 378). McCannon näkee tulevaisuuteen, jossa valkoisen ja mustan polarisaatio on hävinnyt ja jossa hybridiys on normi (vrt. Smith 2004, 146). Etelää ja sen kautta koko Yhdysvaltoja koskeva ongelma on juuri tässä: kysymys amerikkalaisuuden määrittelystä sekoittumisen ja hybridisaation kautta ${ }^{14}$.

Kuten afrikkalaisamerikkalainen intellektuelli W. E. B. DuBois totesi jo 1903, 1900-luvun ongelma on kysymys roturajoista (DuBois 1969). Ja tähän pitää lisätä: eikä rotukysymystä olisi ilman kolonialismia. 


\section{Viiteet}

${ }^{1}$ Artikkeli on laajennettu ja uudelleenkirjoitettu versio KTS:n seminaarissa Helsingissä 20.1.2006 pitämästäni esitelmästä. Kiitokset referee-lukijoilleni.

${ }^{2}$ Kyse ei ole vain vertailusta vaan teosten välisestä suhteesta avautuu reitti Faulknerin tuotannolle ominaisesta kirjailijan/kertojan ja teoksen / kertomuksen väliseen huojuntaan (oscillation), joka tuottaa tietynlaisen kahdentuman (doubling), jossa kirjailija toistamalla ja toisentamalla itseään käy kostonhimoista kamppailua aikaa vastaan (ks. Irwin, 1975, Johdanto).

${ }^{3}$ Webster's Collegiate Dictionary. Springfield, Massachusetts: G. \& C. Merriam, 1981.

${ }^{4}$ Manikealaisella kuvastolla tarkoitan erityisesti vastakohtaparien muodostamaa metaforista tai tropologista rakennetta, joka on luonteenomainen kolonisoijan ja kolonisoidun välisissä kohtaamisissa ja maailman hahmottamisen tavoissa (ks. JanMohamed 1985). Rakenteen metaforisuus tai tropologisuus viittaa siihen lähtökohtaan, että rakenteen esiintyminen on osin käyttäjänsä hallitsemattomissa.

${ }^{5}$ Näitä joitakin salaisuutta piilottelevia ja/tai kirouksen merkitsemiä taloja ovat esimerkiksi E. A. Poen "Usherin talo" ("The Fall of the House of Usher"), Nathaniel Hawthornen Pynchonin talo (The House of Seven Gables, 1851), Daphne de Maurierin Manderley (Rebecca, 1938), Stephen Kingin Overlook-hotelli (The Shining, 1977). André Brinkin apartheidin jälkeiseen Etelä-Afrikkaan sijoittuvassa romaanissa The Rights of Desire (2001) päähenkilön talossa kummittelee orjanainen.

${ }^{6}$ On totta, että Rochesterin näkö palautuu ja hän saa lapsen Jane Eyren kanssa, joten viime kädessä koloniaalinen kirous mitätöityy ja Charlotte Brontën romaani saa onnellisen sulkeuman. Luennassani kuitenkin korostan symbolisen kastraation mahdollisuutta. Toisin kuin paholaismaisella Thomas Sutpenilla, kristinusko ja Jumalan armo takaavat perheonnen Rochesterille ja Jane Eyrelle.

${ }^{7}$ Kanadassa "bush" tarkoittaa suunnilleen samaa kuin "erämaa" ("wilderness"), johon kanadalaisessa kirjallisuudessa joko eksytään tai jossa tullaan hulluksi.

${ }^{8}$ Louisianan orjakapinaan osallistui 300-500 orjaa, ja se onkin ainoa Yhdysvalloissa tapahtunut kapina, jota voi laajuudeltaan verrata Karibian alueella syntyneihin kapinoihin. Muut kapinat Yhdysvalloissa olivat suhteellisen pieniä, esimerkiksi Nat Turnerin kapinaan osallistui noin 70 orjaa. Gabriel Prosser ja Denmark Vesey ilmeisesti olettivat saavansa joukkoihinsa lisäväkeä paljon enemmän kuin mitä todellisuudessa tapahtui (ks. Genovese 1972/1974, 588). Kirjallisuudentutkijat tuntevat parhaiten Nat Turnerin kapinan William Styronin romaanin The Confessons of Nat Turner (1967), Nat Turnerin kapina (1969) kautta. ${ }^{9}$ Ks. Koichi Ohara: "The Subaltern Can Still Speak: A Report on the Puebla Conference", International Gramsci Society Online Article, January 2004. http:www.italnet.nd.edu/gramsci/ resources/online_articles/articles/ohara-2004.shtml, luettu 14.2.2007.

${ }^{10}$ Afrikkalaisamerikkalaisten ja valkoisten köyhien tilasta Etelässä ks. esim. Richard Wright: Black Boy (1945) ja James Agee: Let Us Now Praise Famous Men (1941).

${ }^{11}$ Käsitellessään teollistuneen ja vauraan Pohjois-Italian ja agraarisen ja köyhän Etelä-Italian suhdetta Gramsci kirjoittaa, että suhde on mahdollista hahmottaa "puolittain kolonisoivana" (Gramsci 1971, 90-102). Ks. myös kolonisoivien puhetapojen käytöstä valtion eri osien välisten valtasuhteiden kuvauksessa Pohjoinen-Etelä -akselilla Suomessa ja Norjassa, Ripatti \& 
Kähkölä (1970) ja Brox (1984).

${ }^{12}$ Analogioiden käytöstä heuristisena välineenä historiallisten tapahtumien ymmärtämisessä kiitän inspiroivista keskusteluista professori Markku Hyrkkästä (Historian laitos, Tampereen yliopisto, 22.-23.3.2007).

${ }^{13}$ Baker huomauttaa kiinnostavasti, että Faulkner ei kumma kyllä kirjoita jälleenrakennuksen ajasta ja sitä seuranneista vuosikymmenistä: hänen Yoknapatawphan saagassaan on katkos vuosina 1866-1902. Baker otaksuu, että Faulkner on tietoisesti tai tiedostamattaan torjunut tämän kipeän ajanjakson. (Baker 2000, 28, 134.) Tämä täysin kohdallinen huomautus mielestäni sotii Bakerin esittämää argumenttia vastaan Faulknerin "jälkikoloniaalisuudesta", sillä jos Faulkner olisi keskittynyt juuri sisällissotaa seuranneeseen kauteen 1900-luvun alkuun, voisi olla perustellumpaa tarkastella häntä jälkikoloniaalisesta näkökulmasta.

${ }^{14}$ Karibian ja Väli-Amerikan suuntaan katsottaessa on luonnollisesti huomioitava afrikkalaisamerikkalaisten lisäksi myös latinalaisamerikkalainen vaikutus, ks. esim. Gloria Anzaldúan teos Borderlands / La Frontera, The New Mestiza (1987).

\section{Lähteet}

AHMAD, AIJAZ 1992/2000: In Theory. Classes, Nations, Literatures. London \& New York: Verso.

anZaldúa, GLORIa 1987: Borderlands / La Frontera, The New Mestiza. San Francisco: Aunt Lute Books.

BAKer, CHARLeS 200 I: William Faulkner's Postcolonial South. New York \& Washington D.C.: Peter Lang.

Brontë, Charlotte i 99i: Jane Eyre. Oxford \& New York: Oxford University Press. Brox, OtTAR 1984: Nord-Norge, Fra allmenning til koloni. Tromso, Oslo, Bergen \& Stavanger: Universitetsforlaget.

conrad, Joseph i967: Youth: A Narrative, Heart of Darkness, The End of the Tether. London: Dent, Everyman's Library.

CONRad, JOSEPh 2005: Pimeyden sydän (PS). Suomentanut Kristiina Kivivuori. Helsinki: Otava.

Dubois, w. E. B. I 903/I969: The Souls of Black Folk. New York: Penguin Books / Signet Classic.

FANON, FRANTZ 2003: Sorron yöstä. Suomentanut Hilkka Mäki. Helsinki: Like.

faulKner, william 1936: Absalom, Absalom! (AAE) New York: Random House, The Modern Library.

faulKner, William i967: Absalom, Absalom! (AAS) Suomentanut Kai Kaila. Helsinki: Tammi.

Genovese, Eugene D. I972/1974: Roll, Jordan, Roll. The World the Slaves Made. New York: Pantheon Books/ Random House. 
Genovese, eugene D. 1979/1981: From Rebellion to Revolution. Afro-American Slave Revolts in the Making of the Modern World. Baton Rouge \& London: Louisiana State University Press.

GIlbert, SANDra M. \& GUbAR, SUSAN I979/1984: The Madwoman in the Attic. The Woman Writer and the Nineteenth-Century Literary Imagination. New Haven, Conn.: Yale University Press.

GODden, Richard I994: "Absalom, Absalom! and Faulkner's Erroneous Dating of the Haitian Revolution". The Mississippi Quarterly, Vol. 47, No. 3.

GRAMSCI, ANTONio I97I: Selections from the Prison Notebooks. Toimittaneet ja kääntäneet Quintin Hoare \& George Nowell Smith. London: Lawrence and Wishart.

GRAY, RICHARD I986: Writing the South. Ideas of an American Region. Cambridge \& London: Cambridge University Press.

GRAY, RICHARD 2000: Southern Aberrations, Writers of the American South and the Problems of Regionalism. Baton Rouge: Louisiana University Press.

HARris, Wilson i 983: The Womb of Space. The Cross-Cultural Imagination. Westport, Connecticut \& London, England: Greenwood Press.

IRwin, John T. 1975/I977: Doubling \& Incest, Repetition \& Revenge, A Speculative Reading of Faulkner. Baltimore \& London: The Johns Hopkins University Press. JAMES, C. L. R. I938/I980: The Black Jacobins. Toussaint L'Ouverture and The San Domingo Revolution. London: Penguin Books.

JANMOHAMED, ABDUl R. I985: "The Economy of Manichean Allegory: The Function of Radical Difference in Colonialist Literature. Critical Inquiry, Vol. 12, No. 1, 59-87.

KING, RICHARD H. I980: A Southern Renaissance. The Cultural Awakening of the

American South. New York \& Oxford: Oxford University Press.

MarTIN, S. I. 2000/I999: Britain's Slave Trade. London: Channel 4 Books /

Macmillan.

MATTHEWS, JOHN T. 2004: "Recalling the West Indies: From Yoknapatawpha to Haiti and Back". American Literary History, Vol. 16, No. 2, 238-262.

memmi, AlBert 1957/1974: The Colonizer and the Colonized. Kääntänyt Howard Greenfeld. London: Souvenir Press, A Concord Book (Alkuteos Portrait du colonisé $d u$ portrait du colonisateur).

PARRY, Benita I995: "Problems in Current Thoeries of Colonial Discourse". The PostColonial Studies Reader. Toimittaneet Bill Ashcroft, Gareth Griffiths \& Helen Tiffin. London \& New York: Routledge, 36-44.

PETERSON, CHRISTOPHER 2004: "The Haunted House of Kinship, Miscegenation, Homosexuality, and Faulkner's Absalom, Absalom?'. CR: The New Centennial Review, Vol. 4, No. 1, 227-265.

PUNTER, DAVID \& BYRON, GLENNIS 2004: The Gothic. Oxford: Blackwell. 
SAGE, victor I990: "Introduction". The Gothic Novel. Toimittanut Victor Sage.

London: MacMillan, 8-28.

Rhys, JeAn I983: Wide Sargasso Sea. Harmondsworth, Middlesex, England: Penguin

Books.

RIPATTI, AKU-KIMMO \& KÄHKÖLÄ, PAAVO I 970: Siirtomaasuomi. Jyväskylä: Gummerus.

SAID, EDWARD W. I993: Culture and Imperialism. London: Chatto \& Windus.

Savolainen, MatTi i998: "The Intellectual, the Exile, the Amateur. Contrapuntal

Reading as a Form of Resistance in the Work of Edward Said”. Suomen antropologi, Vol.

23, No. 3, 20-29.

SAVOLAINEN, MATTI I992: "Gotiikka eilen ja tänään”. Teoksessa Haamulinnan perillisiä.

Artikkeleita kauhufiktiosta 1760-luvulta 1990-luvulle. Toimittaneet Matti Savolainen ja

Päivi Mehtonen. Helsinki: Kirjastopalvelu, 9-39.

SCHUeller, Malini JOHar 2004: "Postcolonial American Studies". American Literary

History, Vol. 16, No. 1, 162-175.

SMITH, JON 2004: "Postcolonial, Black, and Nobody's Margin: The US South and the New World Studies", American Literary History, Vol. 16, No. 1, 144-161.

SPIVAK, GAYATRI CHAKRAVORTY I988/I987: "Subaltern Studies: Deconstructing

Historiography". In Other Worlds. Essays in Cultural Politics. New York \& London:

Routledge, 196-221.

SPIVAK, GAYATRI CHAKRAVORTY I988: "Can the Subaltern Speak?". Teoksessa

Marxism and the Interpretation of Culture. Urbana \& Chicago: University of Chicago

Press, 271-313.

SPIVAK, GaYATRI CHAKRAVORTY I989: "Three Women's Texts and a Critique of Imperialism". The Feminist Reader. Essays in Gender and the Politics of Literary Criticism. Toimittaneet Catherine Belsey \& Jane Moore. Basingstoke: Macmillan.

SPIVAK, GaYATRI CHAKRAVORTY I995: "The Author in Conversation" ja "Translator's Preface”. Mahasweta Devi: Imaginary Maps. Three Stories. Kääntänyt Gayatri Chakravorty Spivak. New York \& London: Routledge, ix-xxix. 